\title{
TREATMENT OF GAS GANGRENE INFECTIONS IN GUINEA-PIGS \\ WITH NEOPRONTOSIL, SULFANILAMIDE, AND SULFAPY- \\ RIDINE: AN EXPERIMENTAL STUDY
}

Bx DOUGLAS B. KENDRICK, JR.1

(From the Institute of Experimental Medicine, The Mayo Foundation, Rochester, Minn.)

(Received for publication May 11, 1939)

The development at the end of the World War of an antitoxin for the prophylaxis and treatment of gas gangrene infections provided a method which, in the hands of some men, has been of great value in helping to reduce the mortality rate of this infection. Ghormley (1) has called attention to the beneficial results obtained by the use of antitoxin. He reported a mortality rate of 42.5 per cent in gas gangrene infections which compares favorably with the report of the Surgeon-General's Office of a rate of 48.52 per cent in the American Expeditionary Force in France. However, Ghormley stated that 86 per cent of 33 patients with gas gangrene infections recovered following the use of antitoxin. He stressed the point that antitoxin is of value in the treatment of this infection when given early. Stone and Holsinger (2) reported 67 cases of gas infection with a mortality rate of 32.4 per cent. When antitoxin was used the rate was reduced to I5.3 per cent. On the other hand, Boland (3), reporting a group of 15 cases of gas infection associated with compound fractures, found that when antitoxin was used 4 of these patients died and 4 lived; when antitoxin was not used 2 died and 5 lived. However, the number of cases is too small to be statistically significant. Bohlman (4) reported disappointing results when gas gangrene infections were treated with antitoxin.

Owing to the discrepancies found in the literature on the results obtained when antitoxin was used in gas gangrene infections one is led to believe that it is far from being dependable in the majority of cases of the infection. For this reason many attempts have been made to find other methods of treatment. Sulfanilamide has been tried by several workers for this purpose. Bohlman (4) reported 3 cases of gas gangrene infection treated with sulfanilamide without a fatal-

1 Captain Medical Corps, United States Army, on assignment in The Mayo Foundation. ity. These patients had received 10,000 units of combined gas bacillus antitoxin on admission but were given no antitoxin after the diagnosis of gas gangrene was made. The presence of Clostridium welchii in the wounds of 2 of the patients was not confirmed by laboratory methods. Treatment consisted primarily of sulfanilamide by mouth for several days. Mellon, Gross, and Cooper (5) reported one case of gas gangrene treated with sulfanilamide. This patient had a chronic prostatic disease and a severe diabetes, and a gas infection had developed as the result of catheterization. Large doses of sulfanilamide failed to improve the infection. Long and Bliss (6) working on gas gangrene infection in mice produced experimentally by injecting washed cultures of Clostridium welchii, have shown that sulfanilamide protects mice infected with Clostridium welchii very effectively. In 3 experiments in which Clostridium welchii was resuspended in broth, 36 of 50 treated mice ( 72 per cent) survived. Only 2 out of 27 untreated mice, used as controls, survived the injection of $0.5 \mathrm{cc}$. of the culture. The results obtained by these workers, using unwashed cultures, were disappointing.

The results of a series of experiments to determine the protection afforded by sulfanilamide, neoprontosil, and sulfapyridine in the treatment of gas gangrene infections produced experimentally in guinea-pigs are here reported.

\section{METHODS}

The cultures of Clostridium welchii used in this work were obtained from 2 different sources. The first strain was collected from a nonfatal case of gas gangrene in a human. The second strain was obtained from an elk that had died from a gas gangrene infection. The organisms were isolated from the spleen of the elk and transferred to brain broth mediums for culturing. Cultures incubated at $37^{\circ} \mathrm{C}$. for 24 hours were used in all experiments. Intramuscular injections were done routinely.

In order to determine the smallest quantity required to 
produce a fatal infection consistently, it was necessary to inject graduated amounts of the culture into several guinea-pigs. Three guinea-pigs were injected with 1.0, 0.5 and $0.1 \mathrm{cc}$. of the culture respectively and 3 guineapigs were injected with $0.1 \mathrm{cc}$. of the culture mixed with $0.1 \mathrm{cc}$. of 1-1000 adrenalin. The adrenalin was used to produce a local anoxia so as to increase the chance of an infection developing. The guinea-pigs were dead in 24 hours from extensive gas gangrene infections. Further, to test the amount required to produce fatal infections, cultures were made directly from the guinea-pigs that had died in the previous experiment, and after incubating for 24 hours $0.1 \mathrm{cc}$. of each culture mixed with $0.1 \mathrm{cc}$. of 1-1000 adrenalin was injected into 4 guinea-pigs. Three of the guinea-pigs died from the infection and the fourth, which had been injected with a culture made from the guinea-pig receiving $0.1 \mathrm{cc}$. of culture primarily, had a sloughing lesion of the thigh, but it was not fatal. From these experiments we found that $0.1 \mathrm{cc}$. of the culture mixed with $0.1 \mathrm{cc}$. of $1-1000$ adrenalin would produce fatal lesions regularly.

There is a great deal of variation in the dosage of sulfanilamide advocated for use in small animals. Mellon, Gross, and Cooper (7) recommended giving mice orally doses as small as 0.3 gram and as large as 1.25 grams per kilogram for a period of several days. They considered the large dose to be preferable. Kolmer, Raiziss, and Rule (8) suggested giving sulfanilamide to rabbits in doses varying from 0.1 to 0.5 gram per kilogram orally twice daily. The tolerance of guinea-pigs for sulfanilamide was tested by administering the drug in graduated doses, so that each pig received a different amount. The doses varied from 0.5 gram to 2.0 grams per kilogram. Among the guinea-pigs receiving 2.0 grams per kilogram, marked cyanosis and spastic paralysis of the spinal muscles developed, resulting in death within 24 hours. Doses of 1.5 and 1.0 grams per kilogram caused cyanosis but no paralysis. The pigs receiving 0.5 gram per kilogram showed no untoward results. When $250 \mathrm{mgm}$. of sulfanilamide in $20 \mathrm{cc}$. of physiological saline solution was injected subcutaneously and intraperitoneally into guineapigs, all animals survived; it was, therefore, thought safe to use this dose. In some experiments $350 \mathrm{mgm}$. doses were used perorally twice daily.

Neoprontosil was used initially to determine its therapeutic value in gas gangrene infections. It was injected subcutaneously in $250 \mathrm{mgm}$. doses twice at 6-hour intervals. In this series, as in all the experiments, the first dose of the drug was given when the culture of Clostridium welchii was injected. Sulfanilamide was next employed to determine its efficacy. It was given orally, subcutaneously, and intraperitoneally in doses varying from 250 to $350 \mathrm{mgm}$. twice daily. Finally, sulfapyridine was used to combat the gas infection. Two hundred and fifty milligrams of the drug were given by mouth twice daily.

In the preceding experiments unwashed cultures had been used; owing to the overwhelming infections produced it was thought advisable to use washed cultures to reduce the quantity of preformed toxins in the cultures as suggested by Long and Bliss (6) and by Long (9). A 24-hour brain broth culture (from elk) was washed several times in physiological saline solution by centrifugalization at 1500 r.p.m. for 30 minutes. Then the organisms were diluted to the original volume with physiological saline solution. Then $0.1 \mathrm{cc}$. of the washed culture, mixed with $0.1 \mathrm{cc}$. of 1-1000 adrenalin, was used as the inoculating medium.

\section{RESULTS}

Ten guinea-pigs were inoculated intramuscularly with a 24-hour brain broth culture of Clostridium welchii mixed with $0.1 \mathrm{cc}$. of $1-1000$ adrenalin. Five of the guinea-pigs were treated with $500 \mathrm{mgm}$. of neoprontosil subcutaneously in 2 doses given 6 hours apart. Five guinea-pigs were used as controls. The guinea-pigs in the treated group were dead within 48 hours. Those in the control group were dead within 6 days.

Ten guinea-pigs were inoculated with the standard dose of a culture of Clostridium welchii; 3 were given the culture mixed with $0.1 \mathrm{cc}$. of 1 1000 adrenalin and 3 received the culture without adrenalin. Of the 4 controls, 2 received culture mixed with adrenalin and 2 received the culture without adrenalin. The treated group were given $250 \mathrm{mgm}$. of sulfanilamide at the time the culture was inoculated. Four of the treated group and all of the control group died.

The strain of Clostridium welchii used in the remaining portion of the work was obtained from a fatal case of gas gangrene in the elk.

Ten guinea-pigs were injected with $0.1 \mathrm{cc}$. of culture of Clostridium welchii. Sulfanilamide in $300 \mathrm{mgm}$. doses was given intraperitoneally twice at 6-hour intervals to the treated group. The infection was fatal to the control group in 24 hours and all the treated guinea-pigs were dead in 48 hours.

A comparison of the relative value of sulfanilamide and combined gas gangrene antitoxin was made. Ten guinea-pigs were inoculated with the standard quantity of culture of Clostridium welchii mixed with adrenalin. Four of the treated group received $300 \mathrm{mgm}$. of sulfanilamide subcutaneously twice daily and 3 were given 2000 units of antiperfringens serum when the culture was injected. Three of the guinea-pigs injected. 
with the drug died by the fifth day; the fourth survived. All of the guinea-pigs inoculated with the antitoxin survived. Only one guinea-pig in the control group lived.

Ten guinea-pigs were inoculated with $0.1 \mathrm{cc}$. of a 24-hour culture of Clostridium welchii. The treated group was given $350 \mathrm{mgm}$. of sulfanilamide by mouth twice daily. The guinea-pigs in the treated group were dead within 48 hours and those in the control group died within 60 hours after inoculation.

Two experiments were done to test the efficacy of sulfapyridine in gas gangrene infections. Ten guinea-pigs in each experiment were inoculated with $0.1 \mathrm{cc}$. of a culture of Clostridium welchii. The treated groups were given 250 mgm. of sulfapyridine by mouth twice daily. In the first experiment only 1 out of 5 guinea-pigs in the treated and 1 out of 5 in the control group lived. In the second experiment the infection was fatal to both groups.

Six guinea-pigs were inoculated with $0.1 \mathrm{cc}$. of a washed culture of Clostridium welchii mixed with $0.1 \mathrm{cc}$. of 1-1000 adrenalin. The treated group was given $350 \mathrm{mgm}$. of sulfanilamide by mouth twice daily. The results were practically the same as when unwashed cultures were used. The guinea-pigs in the treated and control groups were dead within 4 days.

A résumé of the results is given in Table $I$.

TABLE I

Results of administering neoprontosil, sulfanilamide, sulfapyridine, or antiperfringens serum to guinea-pigs infected with Clostridium welchis

\begin{tabular}{|c|c|c|c|c|c|c|c|c|c|c|c|c|}
\hline \multirow{2}{*}{$\begin{array}{c}\text { Experi- } \\
\text { ment } \\
\text { number }\end{array}$} & \multirow{2}{*}{$\begin{array}{c}\text { Num- } \\
\text { ber } \\
\text { of } \\
\text { guinea- } \\
\text { pigs }\end{array}$} & \multirow{2}{*}{$\begin{array}{l}\text { Clostridium } \\
\text { welchii } \\
\text { inoculated }\end{array}$} & \multirow{2}{*}{ Treatment } & \multicolumn{8}{|c|}{ Number of deaths } & \multirow{2}{*}{ Survivals } \\
\hline & & & & $\begin{array}{l}1 \\
\text { day }\end{array}$ & $\underset{2}{2}$ & $\begin{array}{c}3 \\
\text { days }\end{array}$ & $\begin{array}{c}4 \\
\text { days }\end{array}$ & $\begin{array}{c}5 \\
\text { days }\end{array}$ & $\begin{array}{c}6 \\
\text { days }\end{array}$ & $\stackrel{7}{\text { days }}$ & $\begin{array}{c}10 \\
\text { days }\end{array}$ & \\
\hline Controls & 35 & 0.1 cc. & None & 15 & 5 & 2 & 3 & 4 & 1 & 1 & 2 & 2 \\
\hline 1 & 5 & $\begin{array}{l}0.1 \text { cc. of Cul- } \\
\text { ture } 1 \dagger\end{array}$ & $\begin{array}{l}250 \text { mgm. of neoprontosil } \\
\text { subcutaneously twice at } \\
\text { 6-hour intervals }\end{array}$ & 2 & 3 & & & & & & & 0 \\
\hline 2 & 6 & $\begin{array}{l}3 \text { guinea-pigs } \\
\text { given } 0.1 \text { cc. of } \\
\text { Culture, } 1 \text { with } \\
\text { adrenalin. } 3 \\
\text { guinea-pigs } \\
\text { given } 0.1 \text { cc. of } \\
\text { culture, } 1 \text { with- } \\
\text { out adrenalin }\end{array}$ & $\begin{array}{l}250 \text { mgm. of sulfanilamide } \\
\text { intraperitoneally. Only } \\
1 \text { dose injected }\end{array}$ & & & & & & & & 4 & $\begin{array}{l}2 \\
\text { (They re- } \\
\text { ceived } \\
\text { culture } \\
\text { only) }\end{array}$ \\
\hline 4 & 4 & $\underset{\text { ture } 2}{0.1}$ cc. of Cul- & $\begin{array}{l}300 \text { mgm. of sulfanilamide } \\
\text { subcutaneously twice } \\
\text { daily }\end{array}$ & 1 & 1 & & & 1 & & & & 1 \\
\hline 5 & 5 & $\begin{array}{l}0.1 \text { cc. of Cul- } \\
\text { ture } 2\end{array}$ & $\begin{array}{l}350 \text { mgm. of sulfanilamide } \\
\text { orally twice daily }\end{array}$ & 1 & 4 & & & & & & & 0 \\
\hline 6 & 10 & $\begin{array}{l}0.1 \text { cc. of Cul- } \\
\text { ture } 2\end{array}$ & $\begin{array}{l}250 \text { mgm. of sulfapyridine } \\
\text { orally twice daily }\end{array}$ & 6 & 3 & & & & & & & 1 \\
\hline 7 & 3 & $\begin{array}{l}0.1 \text { cc. of Cul- } \\
\text { ture } 2 \text { washed }\end{array}$ & $\begin{array}{l}350 \text { mgm. of sulfanilamide } \\
\text { orally twice daily }\end{array}$ & & 1 & & 2 & & & & & 0 \\
\hline
\end{tabular}

* Treated with neoprontosil, sulfanilamide, or sulfapyridine.

t Culture 1 obtained from a nonfatal case in a human. Culture 2 obtained from a fatal case of gas gangrene in elk. 


\section{SUMMARY}

A series of experiments has been done to study the therapeutic value of neoprontosil, sulfanilamide, and sulfapyridine in gas gangrene infections produced experimentally in guinea-pigs. The results obtained with the 3 drugs were very similar. In the doses used, whether the cultures were washed or unwashed, these drugs did not provide protection against the infection. In the treated group there was a mortality rate of 89.5 per cent, while in the control group the rate was 94.3 per cent.

A comparison has been made between the protective value of antiperf ringens serum and sulfanilamide in gas gangrene infections in guineapigs. The antiperfringens serum proved to be much more effective. In spite of the small number of guinea-pigs treated with the serum the difference in results is statistically significant.

\section{REFERENCES}

1. Ghormley, R. K., Gas gangrene and gas infections. J. Bone and Joint Surg., 1935, 17, 907.

2. Stone, C. S., Jr., and Holsinger, H. B., Diagnosis and treatment of gas bacillus infection. Virginia $M$. Monthly 1934, 61, 200.
3. Boland, F. K., Gas gangrene in compound fractures. Ann. Surg., 1929, 90, 603.

4. Bohlman, H. R., Gas gangrene treated with sulfanilamide; report of three cases. J. A. M. A., 1937, 109, 254.

5. Mellon, R. R., Gross, Paul, and Cooper, F. B., Sulfanilamide therapy of bacterial infections with special reference to diseases caused by hemolytic streptococci, pneumococci, meningococci and gonococci. Charles C. Thomas, Springfield, Illinois, 1938, pp. 5, 217.

6. Long, P. H., and Bliss, E. A., Observations upon experimental and clinical use of sulphanilamide in treatment of certain infections. Canad. M. A. J., 1937, 37, 457.

7. Mellon, R. R., Gross, Paul, and Cooper, F. B., Sulfanilamide therapy of bacterial infections with special reference to diseases caused by hemolytic streptococci, pneumococci, meningococci and gonococci. Charles C. Thomas, Springfield, Illinois, 1938, p. 33.

8. Kolmer, J. A., Raiziss, G. W., and Rule, Anna M., Sulfanilamide and diaminodiphenylsulfone and their diacetyl derivatives in treatment of experimental intradermal streptococcus infections of rabbits. Proc. Soc. Exper. Biol. and Med., 1938, 39, 95.

9. Long, P. H. Personal communication through Colonel Siler to the author. 